Історико-політичні проблеми сучасного світу: Збірник наукових статей. - Чернівці: Чернівецький національний університет, 2020. - T. 42. - C. 136-147

DOI: $10.31861 / \mathrm{mhpi} 2020.42 .36-147$

\section{УДК 327.88(470:438)}

Modern Historical and Political Issues: Journal in Historical \& Political Sciences. - Chernivtsi: Chernivtsi National University, 2020. - Volume. 42. - pp. 36-147 DOI: $10.31861 / \mathrm{mhpi} 2020.42 .36-147$

(C) Віра Бурдяк ${ }^{1}$

\title{
Тенденції авторитаризму і популізму в діяльності політичних лідерів та партій Болгарії
}

Автор аналізує прояви популізму й авторитаризму в Болгарії, тісний зв'язок з комуністичним минулим, незрілістю демократичної системи і культури. За роки демократизації та членства в ЄС цінності демократії ще не встигли міцно вкоренитися в свідомості болгар, які регулярно віддають перевагу «харизматичній особистості». Аналіз засвідчив, що підтримка демократичних інститутів в країні низька, що криза довіри до інститутів держави і політичного класу, розчарування в реаліях європейської інтеграції формують ідеологічний вакуум. Доведено, що популізм правлячих партій і опозиції не може мобілізувати громадськість на вирішення економічних і політичних проблем держави у демократичних межах; що протестні мітинги болгар, спричинені низьким рівнем життя, популізмом, високим рівнем корупції, безпорадністю чи й небажанням урядів їх викорінити, не припиняються впродовж тривалого часу. Тож, автор вважає, що в Болгарії інститути демократії ще не зміцніли, а тому загроза реверсу авторитаризму реальна. Впевненість, що держава не зверне з демократичного шляху, буде тоді, коли виклики авторитаризму та популізму, які стоять перед Болгарією, СС та Європою, будуть подолані.

Ключові слова: Республіка Болгарія, Європейський Союз, політичні партії, політичні лідери, авторитаризм, популізм, президентські та парламентські вибори.

\section{Trends of Authoritarianism and Populism in the Activities of Political Leaders and Parties in Bulgaria}

The author analyzes the manifestations of populism and authoritarianism in Bulgaria, their close connection to the recent communist past, the immaturity of the democratic system and culture. Over the years of democratization and EU membership, the values of democracy, in particular: freedom, responsibility, willingness to compromise, respect for democratic procedures and processes, have not yet been strengthened in the minds of Bulgarians, who regularly prefer a "charismatic personality". Support for democratic institutions in the country is low.

Despite the mechanisms of cooperation and inspections, the European Commission annually reports serious problems with corruption and bribery in the higher authorities, administration, judicial proceedings, and the prosecutor's office. The analysis showed that support for democratic institutions in the country is low, that the crisis of confidence in the institutions of the state and the political class, frustrations in the realities of European integration create an ideological vacuum. Populism, in contrast to traditional ideological systems, deeply depends on the peculiarities of national political culture, a specific set of circumstances of socio-economic and political life of the country. In the history of Bulgaria, populism has manifested itself in different ways and on a large scale.

It is proved that the populism of the ruling parties and the opposition cannot mobilize the public to solve the economic and political problems of the state within democratic limits; that Bulgarians' protests, caused by low living standards, populism, high levels of corruption, helplessness, or the reluctance of governments to eradicate them, have not stopped for a long time. Wherever populist leaders came to power, it acquired an authoritarian character, accompanied by abuses and harassment (but not destruction) of the opposition. History knows the sad examples of democracies when authoritarian leaders came to power.

\footnotetext{
${ }^{1}$ Доктор політичних наук, професор кафедри політології та державного управління Чернівецького національного університету імені Юрія Федьковича, Україна. E-mail: vira.burdjak@gmail.com; htts://orcid.org/ 0000-0003-0037-2173.
} 
Therefore, the author believes that the institutions of democracy in Bulgaria have not yet strengthened, and therefore there is a real threat of reversal of authoritarianism. Confidence that the state will not deviate from the democratic path, will then, when the challenges of authoritarianism and populism are overcome, facing Bulgaria, the EU and Europe.

Keywords: Republic of Bulgaria, European Union, political parties, political leaders, authoritarianism, populism, presidential and parliamentary elections.

Постановка наукової проблеми та ії значення. Авторитарні тенденції, значне зростання популізму та ідеологічна нестійкість партій, політиків і суспільства в цілому - ознака багатьох нових країн, що стали на шлях демократії. Після зміни політичного режиму колишні комуністи швидко і масово «перейшли» в табір лібералів, консерваторів, соціалістів і націоналістів. Така зміна політичного світогляду могла відбутися лише у випадку збереження звичної моделі мислення, при якій панував не закон, а поняття «доцільності». Свропейські цінності нові «демократи» розуміють по-своєму, їм «допомагає» минулий досвід, а зацікавленість ЄС у розширенні на Схід, дозволяє діяти в межах звичних імперативів. Ментальний зв'язок з соціалістичним минулим допоміг більшості політиків довільно інтерпретувати поняття «диктатури закону».

У більшості балканських країн на всіх ідеологічних платформах присутній популізм. Переходи «від лібералізму до націоналізму, від націоналізму до консерватизму транзитом через захист традиційних цінностей, 3 підсумковим поверненням в лоно демократії» відбуваються на Балканах легко і невимушено, на рівні політичних асоціацій і приватних біографійㄹ. Глобальна криза найсильніше вразила саме цей регіон. Зниження рівня життя в балканських країнах сприймають найперше як результат реформ, нав'язаних Брюсселем. Так, у сучасній Болгарії утверджуються немислимі для західної цивілізації пріоритети «справедливості» і дій «по совісті» у вигляді законів i, навпаки, закони зневажаються заради «справедливості» і «по совісті». Політики часто трактують закони на власний розсуд, використовують їх в якості інструментів політичної боротьби. Тож, ця проблема залишається доволі актуальною і важливою.

Аналіз останніх досліджень із цієї проблеми. Розгляд тенденцій розвитку і поширення авторитаризму та популізму в діяльності політичних лідерів та партій фокусує значну увагу міжнародної та вітчизняної наукової спільноти. На заході означені проблеми аналізували П. Бурд’є, Е. Лаклау, М. Кастельс, М. Канован, П. Тагарт, К. Мудде, Й. Рідгрен, Ж.-Ф. Сірінелі, Ж.-П. Ріу, Ж. Шевальє, Р. Янсен та ін. В останні роки значно зріс інтерес українських науковців до дослідження цих питань, зокрема до них звертаються В. Бебик, Д. Богуш, В. Бурдяк i Ю. Макар, М. Головатий, М. Дем'яненко, О. Іваницька, А. Колодій, А. Круглашов, Н. Ротар та ін. Досить плідно над дослідженням проблеми популізму працює I. Кіянка, яка підготувала статті, монографію і докторську дисертацію (2017 р.) на тему: «Історичні форми концептуалізації популізму як категорії політичної науки та ідеологічної норми»³.

Вчені аналізують сучасний популізм як політичні рухи, що позиціонують себе захисниками інтересів широких мас, невдоволених умовами життя, та пропонують гучні і прості рішення соціальних проблем. Німецький вчений К. Мудде визначає популізм як ідеологію, що ділить суспільство на групи антагоністів - «народ» та «корумповану еліту» і вимагає перетворити політику на вияв загальної волі першої групи ${ }^{4}$. Його співвітчизники Ю. Мени і Ю. Сурель наголошують, що цей феномен розмиває суспільні горизонтальні поділи (зокрема між лівими та

\footnotetext{
${ }^{2}$ Когда народ за коррупцию. Уроки румынского: чтобы оборонять власть от независимого прокурора пришлось собирать «ручной майдан» (2018), за адресою: www.novayagazeta.ru/articles /2018/07/22/77253kogda-narod-zakorruptsiyu (станом на дату 12 квітня 2019).

${ }^{3}$ Кіянка I. (2016), Популізм в історії та сучасності: ідеологічні течії, рухи та політичні технології: монографія, Львів, Вид-во ТзОВ «Простір-М», 387с; Кіянка І. Б. (2015), «Популізм у програмах політичних партій у контексті державного управління: досвід країн Центрально-Східної Європи», Науковий вісник Ужгородського національного університету, Серія: Політологія. Соціологія. Філософія, Ужгород, Вип. 18, сс. 89-92; Кіянка І.Б. (2014), «Популізм як феномен політичного життя», Вісник Дніпропетровського університету, Серія: Філософія. Соціологія. Політологія. Дніпро, Вип. 23, Т. 21, № 9/2, сс. 24-29; Кіянка І.Б. (2015), «Популізм як політологічна категорія», Науковий журнал Дніпропетровського національного університету імені Олеся Гончара, Філософія і політологія в контексті сучасної культури, Дніпропетровськ, №1, сс. 67-75.

${ }^{4}$ Mudde C., (2004), «The Populist Zeitgeist», Government and Opposition, Vol. 39 (4), pp. 543.
} 
правими партіями та їх прихильниками) 5 . Натомість Д. А. Ланко підкреслює, що сучасні популісти в своїй риториці прагнуть «розрубати гордіїв вузол політики мечем простих рішень» та порушують дискурсивні табу, які склалися у суспільстві

Зауважимо, що питання про причини електоральних успіхів популістів турбує сучасних дослідників навіть більше ніж питання про суть популізму. На думку лівого теоретика Ш. Муфф, правий популізм посилює відсутність реальних політичних дебатів: в умовах домінування «ліберального компромісу» всі не згідні з домінуючими дискурсивними практиками оголошуються «не розумними» та виштовхуються за межі політичного поля. Саме ці голоси згодом каналізують популістські партії․ Популісти роблять утопічні заяви, які не планують виконувати; культивують недовіру до еліт, представницьких державних органів та механізмів, пропонують пряму участь населення в управлінні державою; обирають харизматичного вождя, що відіграє роль «народного трибуна».

Джерельною базою дослідження кейсу Болгарії стали звіти інституцій $\mathrm{CC}$, результати опитувань громадської думки з питань, пов'язаних із демократизацією держави, наукові розвідки дослідників: Д. Смілова, І. Кристєва, А. Тодорова, А. Кристєвої, Г. Карасімеонова, С. Малінова, С. Андреєва, М. Любенова, І. Знепольскі, М. Пиргової та ін. Слід зауважити вагоме дослідження в докторській дисертації І. Димової «Новий популізм та криза представницької демократії» та ряд іiі статей по означеній проблемі ${ }^{8}$. Втім, діяльність болгарських політиків та політичних партій, зокрема в ракурсі предмету дослідження та в контексті порівняльного аналізу, ще не стали об’ єктом значної дослідницької уваги.

Формулювання мети та завдань статті. Метою даного дослідження $є$ вивчення тенденцій авторитаризму та популізму в діяльності окремих політичних лідерів і партій Республіки Болгарія, що неоднозначно впливає на інші праві і традиційні консервативні політичні сили, пов'язані з протестом мас проти політичних еліт. Відповідно до поставленої мети, визначені основні завдання статті: розкрити роль і значення особистості політика в суспільному житті болгар; виявити тенденції розвитку політичних партій та партійної системи; дослідити причини масових протестних демонстрацій і невдоволення болгар політикою уряду; проаналізувати специфіку впливу авторитаризму і популізму на суспільство та геополітичні ризики процесу.

Виклад основного матеріалу дослідження. У Болгарії авторитарна традиція проявляється найперше в тому, що в сучасному політичному житті особистість політика, його вміння самостійно «протистояти», «боротися» $\mathrm{i}$ «вирішувати питання», має істотне значення для суспільства. При цьому, значимість того чи іншого політичного актора, визначається не стільки тим, яку він обіймає (обіймав) посаду чи результатами його діяльності, а харизмою особистості, наявністю у нього широкої мережі неформальних зв'язків, які забезпечують йому вплив у суспільстві.

Велику роль у політиці парламентської Республіки Болгарія поряд з прем'єр-міністром відіграє і надзвичайно популярний у суспільстві Президент, який формально виконує представницькі функції. Посаду прем'єр-міністра близько десяти останніх років (з невеликими перервами) займає Бойко Борисов. Нині він обраний на цю посаду втретє поспіль 4 травня 2017 р. ${ }^{9}$ Ще на початку своєї кар'єри Б. Борисов здобув популярність як активний борець з корупцією. Однак, його діяльність як глави виконавчої влади не привела до поліпшення стану справ у суспільстві та в антикорупційній сфері. Втім, популізм, що лежить в основі його політики, і його харизма,

\footnotetext{
${ }^{5}$ Meny Y., Surel Y. (2002), Democracies and the Populist Challenge. New York, Palgrava, p. 12.

6 Ланко Д. (2009), «Популизм и политическое участие: уличные беспорядки в странах Балтийского региона в 2007-2009 гг.», Политическая експертиза: ПолитЭкс, Т. 5, № 2, с. 215.

${ }^{7}$ Moufte Ch. (2009), «The Limits of John Rawl's Pluralism», Theory: A Journal of Social and Political Theory. Democracy. Morality and Punishment, Vol. 56, № 118, pp. 3-10.

8 Димова Исидора (2016), Новите популизми и кризата на представителната демокрация, Автореферат на дисертационен труд за присъждане на образователната и научна степен «доктор» по научната специалност «Политология», София, Университет за национално и световно стопанство; Димова Исидора. (2014), «Лица на популизма в съвременна България», Социални идеи, движения и политики, НПИ «Димитьр Благоев», София, сс. 213-247; Димова Исидора. «Гражданският бунт срещу олигархията в годината на протестите» (2013), Гражданско общество и граждански протести, Фондация «Човещина», Изд. «Авангард Прима», София, сс. 173-184.

9 Прем'єр-міністри Болгарії (2017), за адресою: https://uk.wikipedia. $\quad$ org/wiki/\%D $0 \% 9 F \%$ D1\%80\%D0\%B5\% (станом на дату 10 жовтня 2019).
} 
дозволили Б. Борисову тричі ставати прем’єр-міністром, а його партії чотири рази поспіль перемагати на парламентських виборах.

У 2001 р., ставши головним секретарем Міністерства внутрішніх справ (МВС), Б. Борисов за лічені місяці перетворився на найпопулярнішого політика Болгарії. До моменту вступу на цю посаду він мав у своєму досьє посади командира взводу в протипожежній службі МВС і шефа охорони двох відомих політичних діячів Болгарії - Тодора Живкова та екс-царя Болгарії Симеона Другого Сакскобургготського.

Правління авторитарного вождя Т. Живкова, що обіймав до 1989 р. всі найвищі посади в Болгарії, тривало 35 рр. і було уособленням соціалізму. Погіршення життєвої ситуації в 1990-х pp., невдоволення ходом приватизації та інші негативні наслідки трансформації викликали ще й на початку XXI ст. ностальгію в суспільстві за соціалістичним минулим. І постать Т. Живкова знову стала популярною. А Б. Борисов часто повторював, що хотів би «зробити для країни хоча 6 соту частку того, що зробив для неї Живков» ${ }^{10}$. Посада охоронця вождя, яку займав Б. Борисов на початку кар'єри, створила «йому серед населення репутацію чи не наступника колишнього правителя» ${ }^{11}$.

Повернення до Болгарії колишнього царя Симеона Другого і тріумф його партії на парламентських виборах (партія «Національний рух Симеон Другий» набрала в 2001 p. 42,74\% голосів) викликали справжній переворот у болгарській політичній системі. Частину популярності Симеона Другого отримав і його охоронець Б. Борисов, як «захисник царя». Так, колишній інженерпожежник Б. Борисов, кандидат фізкультурних наук, що має доволі високий зріст $(1,83$ м), потужну статуру, сьомий дан 3 карате, охоронець двох улюблених у суспільстві лідерів, набув надзвичайно привабливий для болгар образ «захисника-генерала», що вміє діяти в екстремальних ситуаціях.

Від початку політичної кар'єри Б. Борисов став значущою суспільною фігурою. Він критикував діючих політиків, причому критика стосувалася не стільки окремих депутатів, міністрів чи партій, скільки всієї політичної системи та політики, як такої. Його візитною карткою стала проста і дещо грубувата, наближена до повсякденної мови манера говорити. Борисов у прямому сенсі «не обирав виразів». Соціологічні опитування показували, що його рейтинг досягав 80-85\%. У 2002 р. Б. Борисова обрали Людиною року Болгарії. Тоді ж почали з'являтися шкільні зошити 3 його зображенням, про нього складали пісні ${ }^{12}$. Без особливих труднощів він переміг на виборах мера Софії в 2005 р. «Звинувачуючи чинну владу в корупції, Борисов продовжив розвивати лінію протистояння з «системою, що прогнила» ${ }^{13}$.

У 2006 р. він оголосив про створення власного руху, а не партії, щоб уникнути асоціації 3 системою, - «Громадяни за європейський розвиток Болгарії» (ГЕРБ) ${ }^{14}$. Популярність Б. Борисова була настільки значна, що прогнози на президентські вибори 2006 р. будувалися, зважаючи на те, чи буде він брати у них участь. Влітку 2009 р. створена Борисовим партія ГЕРБ увійшла до Народних зборів (парламент Болгаріі), набравши 39,72\% голосів виборців. Борисов сформував однопартійний уряд, тому що його Кабінет міністрів підтримали три партії, які також увійшли до парламенту.

Попри проголошення першочерговим завданням ліквідацію корупції, розробку амбітних проектів реформ, відновлення довіри ЄС до Болгарії (кошти ЄС були деблоковані), в свою першу каденцію уряд Б. Борисова не зміг домогтися істотних результатів у поліпшенні соціальноекономічних умов життя болгар. Більше того, в кінці першого терміну, в лютому 2013 р., через енергетичну політику його Кабінету істотно погіршилося матеріальне становище громадян і це

\footnotetext{
${ }^{10}$ Опитите да се въздигне Живков едва ли не до водещ български държавник са жалки (2001), за адресою: www.mediapool.bg/opitite-da-se-vazdigne-zhivkov-edva-line-do-vodesht-balgarski-darzhavnik-sa-zhalkinews 1870 64.html (станом на дату 20 травня 2010).

${ }^{11}$ Там само.

12 Ни цар, ни генерал... (2005), за адресою: www.paragraph22.bg/22-sedmichnik/read/ni-car-ni-general / (станом на дату 10 жовтня 2019).

13 Подчасов Н.А. (2017), «Бойко Борисов: факты биографии», в: Политические лидеры в современной Восточной Европе, Москва, ИНИОН РАН, с. 34.

${ }^{14}$ Граждани за европейско развитие на България (ГЕРБ) (2010), за адресою: www.gerb.bg/bg/news/spisykstanovishta_i_pozicii-3.html (станом на дату 10 квітня 2012).
} 
викликало серйозну суспільно-політичну кризу ${ }^{15}$. У Софії розпочалися безперервні демонстрації. Протестуючі не відреагували ні на відставку міністра енергетики С. Дянкова, ні на відкликання ліцензії у розподільної компанії CEZ. Вони виступали проти всієї політичної системи.

Після сутичок демонстрантів з поліцією 19 лютого 2013 р. Б. Борисов подав у відставку. Він заявив, що не хоче очолювати уряд, що веде війну з власним народом. Таким чином, він у цій ситуації демонстративно зняв з себе відповідальність. Втім, вже у травні 2013 р. на парламентських виборах партія ГЕРБ набрала 30,53\% і знову сформувала найбільшу фракцію в парламенті. Майже десять років поспіль партія Б. Борисова перемагає на виборах, отримуючи свої стабільні понад 30\% голосів виборців.

За роки трансформаційних змін кожна партія Болгарії, що приходила до влади, за роки правління втрачала популярність і на наступних виборах зазнавала поразки. Лише партія ГЕРБ стала винятком. Більше того, будучи при владі майже всі належні чотири роки своєї першої каденції, по суті, ставши ініціатором найбільшої кризи, що викликала масові мітинги протесту, партія ГЕРБ через три місяці після падіння іiі уряду знову виявилася найбільш успішною і популярною, про що свідчать результати наступних виборів.

Цей, на перший погляд, парадокс, можна пояснити за допомогою феномена популізму. Згідно $з$ одним з його визначень, що, на нашу думку, найбільш точно розкриває суть явища, «популізм означає звернення до суспільства емоційною, спрощеною і маніпулятивною мовою чи висунення опортуністичної програми, розрахованої на «купівлю» підтримки» ${ }^{16}$.

Логічно припустити, що болгари оцінили відхід Б. Борисова з посади прем'єр-міністра в момент кризи не як втечу, а прояв послідовності. «Борисов обіцяв своїм виборцям, що буде прем'єром до тих пір, поки народ бажає бачити його на цій посаді - він дотримався слова і пішов, коли народ висловив своє невдоволення» ${ }^{17}$. Популістська програма ГЕРБ та такі ж заяви Б. Борисова, його образ в цілому, відіграли тут головну роль. Цього разу припущення про те, що, швидше за все, політика Б. Борисова, яка викликала кризу, після його повернення на посаду прем'єр-міністра повториться, не стало вирішальним для його виборців. Уміння політика «тримати слово» виявилося для болгар кращим, ніж його здатність відповідально справлятися 3 труднощами і вирішувати нагальні проблеми країни.

Згодом Б. Борисов не раз використовував цей хід. Останні позачергові парламентські вибори в Болгарії відбулися в березні 2017 р. після того, як Б. Борисов пообіцяв і знову виконав свою обіцянку піти у відставку, якщо на президентських виборах у листопаді 2016 р. переможе Румен Радев, в особі якого прем'єр вбачав свого конкурента в боротьбі за популярність, а, отже, і за владу ${ }^{18}$. І в цьому він не помилився, інтуїція його не підвела.

32017 р. болгарське суспільство перманентно охоплюють протести, мітинги, на яких демонстранти звинувачують правлячу коаліцію в корупції та «діях мафіозного характеру» і вимагають відставки прем'єр-міністра Б. Борисова. У липні 2020 р. правляча партія ГЕРБ, реагуючи на демонстрації, вирішила відправити у відставку трьох міністрів - фінансів, економіки та внутрішніх справ. Але це не зупинило протести. Демонстрантів підтримує опозиційна Болгарська соціалістична партія (БСП), а також Президент Р. Радев ${ }^{19}$, який виступає основним критиком уряду Б. Борисова.

Корупція, засилля олігархії, економічна криза і невикорінна бідність болгар - причин доволі багато, щоб підживлювати протест тривалий час, як показали демонстрації 2013-2014 pр., що тривали кілька місяців. У 2020 р. виступи тривають з липня. Вже минуло сто днів від початку масштабних антиурядових мітингів у містах Болгарії. Масові заходи спричиняють блокування ключових дорожніх розв'язок в столиці, зіткнень з органами правопорядку, дискусій в парла-

\footnotetext{
15 Демонстранты в Болгарии требуют отставки правительства (2013), за адресою: www.bbc.com/ russian/rolling_news/2013/06/130623_rn_bulgaria_protests (станом на дату 12 квітня 2016).

${ }^{16}$ Страны Центральной и Восточной Европы - новые члены Европейского союза. Проблемы безопасности (2010), Москва, Наука, с.71.

17 Подчасов Н.А. (2017), «Бойко Борисов: факты биографии», в: Политические лидеры в современной Восточной Европе, Москва, ИНИОН РАН, с. 36.

${ }^{18}$ Bulgarian PM Boricov tendens his government resignation (2016). Reuters. Nov. 14.

${ }^{19}$ В Болгарии возобновились массовые протесты против правительства (2020), за адресою: www.dw.com/ ru/\%D0\%B2-\%D0\%B1\% D0\%BE\%D0\%BB\%D0\%\%B8B5 /a-54192503 (станом на дату 18 серпня 2020).
} 
менті ${ }^{20}$. Уряд не може вирішити проблему мітингів. Навіть, якщо Б. Борисов не витримає натиску і втретє піде у відставку, в доступній для огляду перспективі це мало що змінить ${ }^{21}$.

Чинний Президент Болгарії - колишній командувач болгарськими військово-повітряними силами (ВПС), полковник, льотчик, Р. Радєв став найпопулярнішою фігурою і активною дійовою особою в суспільно-політичному житті Болгарії. Крім професії військового, громадськість країни підкупило його позиціонування себе як позапартійного кандидата, політика, який прийшов захищати національні інтереси держави, і апелювання до необхідності відновлення відносин з Москвою, що зіграло на почуттях любові до Росії у великої частини болгар. Попередній Президент Росен Плевнелієв не балотувався на другий термін, оскільки його проамериканську позицію болгарське суспільство не сприймало.

Тиск, який чинив на громадськість, користуючись своєю популярністю і висуваючи ультиматуми, чинний прем'єр Б. Борисов, був безпрецедентним ${ }^{22}$. Однак, кандидат на посаду президента від його партії Ц. Цачева в другому турі програла Р. Радеву, який набрав $59 \%$ голосів ${ }^{23}$. Натівський генерал, як сам про себе каже, «перший болгарин, який закінчив військовоповітряну академію в США», і має великий досвід польотів на радянських МіГах. А на посаді Президента прагне захищати євроатлантичне безпекове членство Болгарії і розширювати військово-технічну співпрацю з Росією, реалізуючи два популярних в Болгарії гасла, які одночасно суперечать одне одному ${ }^{24}$.

У Болгарії склалася двопартійна система. Програми провідних партій, хоч і створені на різних ідеологічних платформах, фактично не мають розбіжностей, адже їх світоглядні концепції грунтуються на принципах і цінностях демократії та популізмі. Практично всі партії об’єднує прагнення розвиватися демократичним шляхом в межах євроінтеграції, з використанням популістських гасел, таких як боротьба з корупцією, повернення до традиційних національних і духовних християнських цінностей, відродження Болгарії тощо. Основні політичні партії в Болгарії - БСП і ГЕРБ. 3 різною тривалістю і в різних конфігураціях з іншими парламентськими партіями, вони впродовж останніх десяти років здійснюють владу в Болгарії.

БСП позиціонує себе як лівоцентристська соціал-демократична партія. Вона є спадкоємицею Болгарської комуністичної партії (БКП), яка керувала країною з 1944 р. У 1990 р. БКП була перейменована в БСП. 3 цього часу вона самостійно чи в коаліції з іншими партіями і рухами проходила до парламенту всіх скликань. 31999 р. БСП, яка вже втратила монолітність і постійно перебуває у кризі, самостійно не бере участі у виборах, а створює для цього коаліції з дрібнішими партіями, що свого часу відкололися від неї.

Починаючи з 90-х рр., соціалісти втрачають громадську підтримку, їх електорат поступово фізично зменшується. У 2013 р. на виборах в Народні збори БСП отримала 26,6\% голосів, а в 2014 р. - лише $15,4 \%{ }^{25}$, тобто в двічі менше, ніж у ГЕРБ, хоч саме управління останньої за три місяці до виборів довело країну до суспільно-політичної кризи. 32009 р. БСП перейшла в опозицію, відкинувши пропозицію ГЕРБ увійти в урядову коаліцію.

ГЕРБ - правоцентристська консервативна партія, створена в 2006 р. 3 ініціативи тодішнього мера Софії Б. Борисова, на основі ним же створеного дещо раніше однойменного об'єднання.

20 В Болгарии антиправительственные митинги продолжаются уже 100 дней (2020), за адресою: https://rg.ru/2020/10/17/v-bolgarii-antipravitelstvennye-mitingi-prodolzhaiutsia-uzhe-100-dnej.html (станом на дату 21 жовтня 2020).

21 Мафия, вон! Откуда начались и куда ведут протесты в Болгарии (2020), за адресою: https://russiancouncil.ru/analytics-and-comments/analytics/ mafiya-von-otkuda-nachalis-i-kuda-vedut-protestyv-bolgarii/ (станом на дату 30 жовтня 2020).

${ }^{22}$ Борисов обяви официално Цецка Цачева за кандидат-президент на ГЕРБ: Нацията има нужда и от майка (допълнена) (2016), Дневник.bg., 2 октября.

${ }^{23}$ Антова Д. (2016), «Цецка Цачева, вече официално, кандидатът на ГЕРБ за президент», News.bg, 2 октября.

24 Новый президент Болгарии Румен Радев. Я - натовский генерал (2018), за адресою: https://deschide.md/ru/russian_news/externe_ru/3317 / (станом на дату 10 жовтня 2019).

${ }^{25}$ БСП отряза АБВ от преговорите за обща коалиция за президентските избори. От столетницата не са съгласни с предложения от партията на Първанов проект за коалиционно споразумение (2016), Blitz.bg., 23 августа. 
Мета політики ГЕРБ - перемога над злочинністю і корупцією, досягнення високих європейських стандартів, через активну участь у європейській інтеграції та співробітництво з СС і НАТО.

Попри те, що у БСП і ГЕРБ є загальна основа, зокрема чітке переконання у відданості європейському й євроатлантичному вибору Болгарії, їх позиції по основних внутрішніх і зовнішніх політичних питаннях мають розбіжності. Так, якщо правоцентристська ГЕРБ $є$ провідником політики економії - зменшення витрат держбюджету, то соціалісти виступають за підвищення пенсій, зарплат і розширення соціальних пільг. Лідери БСП хочуть бачити Болгарію на чолі боротьби за скасування санкцій проти РФ, за відновлення енергетичних проектів з Росією. А їх опоненти з ГЕРБ - тривалий час були послідовними прихильниками продовження санкцій і дій проти РФ. В цій царині вони мали спільні погляди і підходи з провідними країнами СС, в т.ч. і щодо проведення енергетичної політики.

Втім, зараз позиції БСП і ГЕРБ стосовно енергетичних зв'язків з РФ починають дещо зближуватися. Політика Б. Борисова, спрямована на згортання відносин з Росією в енергетиці (закриття «Південного потоку» і будівництва атомної електростанції в Белене), не привела до отримання «бонусів» від СС. Навпаки, Болгарія, яка вимушена самотужки покривати неустойку РФ за відмову від Белене в розмірі понад 600 млн євро, надала нові можливості для енергетичного розвитку іншим країнам: Німеччині, яка почала будувати з РФ «Північний потік-2», і Туреччині, яка будує «Турецький потік». 32016 р. Борисов налагоджує контакти з РФ, відновлює закриті ним же проекти в сфері атомної і газової енергетики. Адже з 2013 р. енергетична тема, а 32014 р. тема відносин з РФ, стали дуже популярними серед болгар, їх активно пропагують суперники Борисова з БСП, які мають інтерес у цих сферах і підтримку у суспільстві.

3 одного боку, популізм, який лежить в основі болгарської політики, не може мобілізувати громадськість. Жодна 3 партій в Болгарії за останній час не змогла набрати необхідну кількість голосів, щоб, не входячи в коаліцію чи не заручившись підтримкою інших партій, створити однопартійний уряд. 3 іншого боку, ідеологічна лабільність болгарських політиків саме 3 ним пов’язана, що дозволяє створювати широкі парламентські й урядові коаліції.

У посткомуністичний період у Болгарії до складу урядів і парламентських коаліцій входять партії, які теоретично не мають підстав до об'єднання через різні політичні гасла і програми. Ефемерність всіх партійних і парламентських альянсів болгар посилюється відсутністю консолідуючої ідеї, в ролі якої раніше виступала мета вступу в СС.

Єдиним з усіх болгарських урядів, який зумів вирішити всі поставлені завдання і відпрацювати всю свою каденцію, був уряд С. Станішева ${ }^{26}$. Задля досягнення головної мети - вступу в ЄС, БСП, яку він очолював, об'єдналася з партіями «Рух за права і свободи» (РПС) і «Національним рухом Симеона Другого» (НРСВ). Це об'єднання змогло, незважаючи на великі труднощі, створити чіткі орієнтири і дотримуватися їх, що прискорило і полегшило процес реалізації євроінтеграційної стратегії Болгарії.

У 2014 р. Борисову довелося сформувати правоцентристську коаліцію 3 «Реформаторським блоком» (РБ), «Альтернативою за болгарське відродження» (АБВ) і «Патріотичним фронтом» (ПФ). РБ - правоцентристський політичний блок, до складу якого на той час вже входили ліберальні, християнсько-демократичні та консервативні партії, всього - п’ять. Всі вони мали антикомуністичну спрямованість, виступали за енергетичну незалежність від РФ. Натомість АБВ партія з соціал-демократичною ідеологією, яку створив колишній Президент Болгарії і лідер БСП - Георгій Пирванов. АБВ традиційно виступає за розвиток дружніх зв'язків з РФ та реалізацію ідеалів справедливості в розумінні соціалістів. У коаліцію увійшов ще й ПФ - націоналістична коаліція двох партій, які ратують за відродження економіки і «всього болгарського», ведуть боротьбу проти монополій різного штибу і заборони національних партій.

У чинну урядову коаліцію Болгарії, утворену в 2017 р., входять ГЕРБ і «Об’єднані патріоти» (ОП). ОП - це союз трьох партій: «Національний фронт порятунку Болгарії» (НФПБ), «ВМРО Болгарський національний рух» $\mathrm{i}$ «Атака» ${ }^{27}$. «Патріоти» відомі своїми расистськими і ксено-

\footnotetext{
${ }^{26}$ Болгарский социалист С. Станишев: Выборы были нечесными (2013), за адресою: www.rbc.ru/politics/ 13/05/2013/5704084e9a7947fcbd448bb1 (станом на дату 10 жовтня 2020).

27 Симеонов П. ГЕРБ и Обединените патриоти по-скоро имат условия в 44-ото Народно събрание да изпълнят заявените политики (2017), за адресою: www.focus-news.net/opinion/2017/04/18/42635/ parvansimeonov-politolog-gerb-i-obedinenite-patrioti-po-skoro-imat-usloviya-v-44-oto-narodno-Sabranie-da-izpalnyatza-yavenite-politiki (станом на дату 10 жовтня 2019).
} 
фобськими гаслами, закликами заборонити етнічні партії, ввести обмеження для ромів, що живуть у Болгарії ${ }^{2}$. Вони виступають за реформу Євросоюзу, лояльно ставляться до співпраці 3 РФ, в т.ч., і в енергетиці. У чинному уряді Болгарії двоє з чотирьох віце-прем'єрів - представники ОП: голова ВМРО Красимир Каракачанов - міністр оборони, член ВМРО Нено Дімов міністр екології, а голова НФСБ Валері Симеонов керує соціальними питаннями.

Головна відмінність «Атаки» від двох інших партій з ОП, полягає в тому, що вона є єдиною політичною силою євроскептиків у Болгарії. «Атака» виступає за вихід Болгарії з НАТО і ЄС, активно підтримує політику РФ у міжнародних відносинах і вимагає визнання православ'я офіційною релігією. Популярність «Атаки» досягла піку в 2007 р. на виборах до Європарламенту, коли вона набрала 14,2\% голосів. За рік до цього ії лідер Волен Сідеров був реальним претендентом на посаду президента. У 2006 р. у другому турі він програв Г. Пирванову. Однак, в останні роки «Атака» втратила електорат. У 2009 р. на парламентських виборах вона завоювала 9,36\% голосів; у травні 2013 р. - 7,30\%; у 2014 р. - 4,52\% і не пройшла до парламенту. На виборах до Європарламенту 2014 р. вона отримала ще менше - 2,96\% голосів, тож не ввійшла і в законодавчий орган ЄС. Проте, у 2017 р. «Атака» знову увійшла до Народних зборів, але вже в складі ОП. Крім того, в чинному уряді представник ії партії, Еміл Караніколов, займає посаду міністра економіки.

За словами депутата Європейського парламенту і колишнього прем'єр-міністра Бельгії Гі Верхофстадта, в Європі «в 2019 р. розгорнеться боротьба за ліберальну демократію ... проти спроб деяких країн [членів $С$ - В.Б.] ... йти шляхом неліберальної автократії» ${ }^{29}$. Втім, динаміка розвитку внутрішньополітичної ситуації в Болгарії свідчить про те, що навіть якщо це станеться, невідомо, хто з цієї боротьби вийде переможцем.

Більш ефективні заходи впливу (крім чинних) на країни, які відступають від демократичного шляху, Євросоюз лише почав розробляти. Найперше це плани Єврокомісії створити механізм фінансового тиску на країни-члени $\mathrm{CC}$, які порушують власними національними реформами європейські норми демократії. Втім, про нові заходи, як вважає нинішній голова Єврокомісії Жан Клод Юнкер, можна говорити не раніше 2021 р. Більшість болгар, які віддають перевагу авторитарним політикам, харизматичним особистостям, заявляють про свою «позасистемність» i «аполітичність». Виборці у своїх перевагах і політики в своїй діяльності не орієнтуються на ідеологію чи цінності, а часто - і на законність.

Висновки. Проблеми, пов'язані з підготовкою до вступу в СС, та консолідація зусиль держави на виконання євроінтеграційних завдань впродовж трансформаційного періоду, об'єднували в Болгарії правих і лівих, радикалів і консерваторів, політиків і простих громадян. Однак, гострота проєвропейського і прореформаторського консенсусу поступово спадає. Натомість в країні наростають націоналістичні, авторитарні та популістські тенденції в середовищі правлячого класу, як і протестні суспільні настрої проти корупції, бідності, олігархів, в цілому політичного класу, який болгари вважають нездатним і байдужим до їх повсякденних соціальних проблем.

Популізм, який фактично зайняв місце державної ідеології і слугує правлячим партіям та опозиції, не в змозі мобілізувати громадськість на вирішення фундаментальних економічних і політичних проблем у демократичних межах. Його часто використовують в тактиці, але в стратегії - це загрожує демократичному майбутньому Болгарії.

Зростання популізму в країнах-членах ЄС і в Болгарії в т.ч., у певному сенсі - це реакція на інтеграційні процеси та глобалізацію, яка сприяє розмиванню, руйнуванню традиційних національних ідентичностей і надто загострилася в останнє десятиліття, зокрема: 1) болгарські популістські сили в цілому схильні до націоналістичної ідеології та риторики; 2) активізувалося критичне ставлення до СС, намагання послабити вплив глобалізаційних процесів на державу; 3) гостра критика масової імміграції, що визнана загрозою традиційним болгарським цінностям і культурі. Ці особливості загалом наближають болгарських популістів до табору правих ради-

\footnotetext{
${ }^{28}$ Гацак А. Гацак А. (2020), Совет Европы обвинил Болгарию в расизме по отношению к цыганам, за адресою: https://rg.ru/2020/11/03/sovet-evropy-obvinil-bolgariiu-v-rasizme-po-otnosheniiu-k-cyganam.html (cтаном на дату 5 листопада 2020).

29 ИА REGNUM (2015), «Еврокомиссия вновь критикует Болгарию за коррупцию», за адресою: https://regnum.ru/news/1888620.html (станом на дату 12 квітня 2019).
} 
калів, що дає деяким дослідникам підстави вважати, що популізм і правий радикалізм $є$ різновидами однієї ідеології, і різниця між ними має кількісний, а не якісний характер (популісти схильні до менш радикальних рішень). Хоч Болгарія розвивається у межах демократичного суперництва правоцентристських і лівоцентристських сил, в останне десятиліття владу здобули політики, які надто наблизилися до межі, за якою демократія переходить в авторитаризм.

Більшість провідних болгарських політиків перетворилися у замкнутий деідеологізований клас, в якому немас принципової різниці між поглядами урядовців та опозиції. «Лавка запасних» 3 числа професійних політиків, здатних забезпечити безперервність виконання управлінських функцій в Болгарії відсутня. Нових партій і політичних лідерів справді демократичного спрямування в державі за останні десять років не з'явилося. Втім, парадоксом сучасної болгарської політики $є$ те, що елітам водночас вдається ніби неможлива річ: бути легітимними і на глобальному, і на локальному рівнях. Створюється враження, що ні $Є С$, ні представники болгарського правлячого класу, ні громадськість не знають, як вийти із цієї складної ситуації.

На нашу думку, говорити про кризу неоліберальної демократії в Болгарії, під впливом посилення глобалізації, авторитарних та популістських тенденцій, все ж не слід. Втім, втрата ліберально-демократичних цінностей у суспільстві доволі відчутна. На це вказує суспільна підтримка діяльності партій правоцентристського політичного блоку та націоналістичної коаліції. Для вирішення тривалих проблем у межах чинної парламентської системи, Болгарія потребує нових політичних сил, не пов'язаних з олігархією. Окремі нові партії занадто слабкі і непопулярні, щоб кинути виклик таким партіям - лідерам болгарської політики, як ГЕРБ і БСП. Нову політичну силу, яка б здобула необхідну підтримку виборців, міг би створити Президент Р. Радєв, що користується досить високою довірою в суспільстві, але він поки що такої ініціативи не проявляе.

\section{Список джерел:}

1. Антова Д. (2016), «Цецка Цачева, вече официално, кандидатьт на ГЕРБ за президент», News.bg, 2 октября.

2. Болгарский социалист С. Станишев: Выборы были нечесными (2013), за адресою: www.rbc.ru/politics/13/05/2013/5704084e9a7947fcbd448bb1 (станом на дату 10 жовтня 2020).

3. Борисов обяви официално Цецка Цачева за кандидат-президент на ГЕРБ: Нацията има нужда и от майка (допълнена) (2016), Дневник.bg., 2 октября.

4. БСП отряза АБВ от преговорите за обща коалиция за президентските избори. От столетницата не са сьгласни с предложения от партията на Пьрванов проект за коалиционно споразумение (2016), Blitz.bg., 23 августа.

5. Бурдяк В., Макар Ю. (2012), «Популізм - складова діяльності українських політичних партій», Україна - Свропа - Світ, Вип. 10, Тернопіль, Вид-во ТНПУ ім. В. Гнатюка, сс. 130-138.

6. В Болгарии антиправительственные митинги продолжаются уже 100 дней (2020), за адресою: https://rg.ru/2020/10/17/v-bolgarii-antipravitelstvennye-mitingi-prodolzhaiutsia-uzhe-100dnej.html (станом на дату 21 жовтня 2020).

7. В Болгарии возобновились массовые протесты против правительства (2020), за адресою: www.dw.com/ru/\%D0\%B2-\%D0\%B1\% D0\%BE\%D0\%BB\%D0\%\%B8B5 /a-54192503 (станом на дату 18 серпня 2020).

8. Гацак А. (2020), Совет Европы обвинил Болгарию в расизме по отношению к цыганам, за адресою: https://rg.ru/2020/11/03/sovet-evropy-obvinil-bolgariiu-v-rasizme-po-otnosheniiu-kcyganam.html (станом на дату 5 листопада 2020).

9. Граждани за европейско развитие на България (ГЕРБ) (2010), за адресою: www.gerb.bg/bg/news/spisyk-stanovishta_i_pozicii-3.html (станом на дату 10 квітня 2012).

10. Демонстранты в Болгарии требуют отставки правительства (2013), за адресою: www.bbc.com/russian/rolling_news/2013/06/130623_rn_bulgaria_protests (станом на дату 12 квітня 2016).

11. Димова Исидора (2016), Новите популизми и кризата на представителната демокрация, Автореферат на дисертационен труд за присъждане на образователната и научна степен «доктор» по научната специалност «Политология», София, Университет за национално и световно стопанство.

12. Димова Исидора (2014), «Лица на популизма в съвременна България», Социални идеи, движения и политики, НПИ «Димитър Благоев», София, сс. 213-247. 
13. Димова Исидора (2014), «Гражданският бунт срещу олигархията в годината на протестите», Гражданско общество и граждански протести, Фондация „Човещина“, Изд. „Авангард Прима“, София, сс. 173-184.

14. ИA REGNUM (2015), «Еврокомиссия вновь критикует Болгарию за коррупцию», за адpeсою: https://regnum.ru/news/1888620.html (станом на дату 12 квітня 2019).

15. Кіянка I. (2016), Популізм в історії та сучасності: ідеологічні течії, рухи та політичні технології: монографія, Львів, Вид-во ТзОВ «Простір-М», 387с.

16. Кіянка І. Б. (2015), «Популізм у програмах політичних партій у контексті державного управління: досвід країн Центрально-Східної Європи», Науковий вісник Ужгородського національного університету, Серія: Політологія. Соціологія. Філософія, Ужгород, Вип. 18, сc. 89-92.

17. Кіянка І. Б. (2014), «Популізм як феномен політичного життя», Вісник Дніпропетровського університету, Серія: Філософія. Соціологія. Політологія. Дніпро, Вип. 23, Т. 21, № 9/2, сс. 24-29.

18. Кіянка І. Б. (2015), «Популізм як політологічна категорія», Науковий журнал Дніпропетровського національного університету імені Олеся Гончара, Філософія і політологія в контексті сучасної культури, Дніпропетровськ, №1, сс. 67-75.

19. Когда народ за коррупцию. Уроки румынского: чтобы оборонять власть от независимого прокурора пришлось собирать «ручной майдан» (2018), за адресою: www.novayagazeta.ru/articles /2018/07/22/77253-kogda-narod-zakorruptsiyu (станом на дату 12 квітня 2019).

20. Ланко Д. (2009), «Популизм и политическое участие: уличные беспорядки в странах Балтийского региона в 2007-2009 гг.», Политическая експертиза: ПолитЭкс, Т. 5, № 2, сс. 209230.

21. Мафия, вон! Откуда начались и куда ведут протесты в Болгарии (2020), за адресою: https://russiancouncil.ru/analytics-and-comments/analytics/ mafiya-von-otkuda-nachalis-i-kuda-vedutprotesty-v-bolgarii/ (станом на дату 30 жовтня 2020).

22. Ни цар, ни генерал... (2005), за адресою: www.paragraph22.bg/22-sedmichnik/read/ni-carni-general / (станом на дату 10 жовтня 2019).

23. Новый президент Болгарии Румен Радев. Я - натовский генерал (2018), за адресою: https://deschide.md/ru/russian_news/externe_ru/3317 / (станом на дату 10 жовтня 2019).

24. Опитите да се въздигне Живков едва ли не до водещ български държавник са жалки (2001), за адресою: www.mediapool.bg/opitite-da-se-vazdigne-zhivkov-edva-line-do-vodeshtbalgarski-darzhavnik-sa-zhalki-news 1870 64.html (станом на дату 20 травня 2010).

25. Подчасов Н.А. (2017), «Бойко Борисов: факты биографии», в: Политические лидеры в современной Восточной Европе, Москва, ИНИОН РАН, сс. 31-38.

26. Популизм (2010), за адресою: http://dic.academic.ru/dic.nsf/enc3p/ 240534; http://dic.academic. ru/dic.nsf/ politology /173 (станом на дату 22 травня 2014).

27. Прем’ер-міністри Болгарії (2017), за адресою: https://uk.wikipedia. org/wiki/\%D 0\%9F\% D1\% 80\%D0\%B5\% (станом на дату 10 жовтня 2019).

28. Румынию критикуют за правовую реформу (2018), за адресою: https://ru.euronews.com/2018/10/23/brief-romania-hungary-ing-daphne (станом на дату 10 жовтня 2019).

29. Симеонов П. ГЕРБ и Обединените патриоти по-скоро имат условия в 44-ото Народно събрание да изпьлнят заявените политики (2017), за адресою: www.focusnews.net/opinion/2017/04/18/42635/ parvan-simeonov-politolog-gerb-i-obedinenite-patrioti-po-skoroimat-usloviya-v-44-oto-narodno-Sabranie-da-izpalnyat-za-yavenite-politiki (станом на дату 10 жовтня 2019).

30. Страны Центральной и Восточной Европы - новые члены Европейского союза. Проблемы безопасности (2010), Москва, Наука.

31. Barber T. (2012), «Europe must confront crisis of legitimacy». The Financial Times. 24 April.

32. Bulgarian PM Boricov tendens his government resignation (2016). Reuters. Nov. 14.

33. Le populisme ou la democratie des humeurs (2016), available at: www. liberationfr/france/2012/01/02/le-populisme-ou-la-democratie-des-humeurs785319 (accessed 10 October 2019).

34. Meny Y., Surel Y. (2002), Democracies and the Populist Challenge, New York, Palgrava, 259 p.

35. Moufte Ch. (2009), «The Limits of John Rawl's Pluralism», Theory: A Journal of Social and Political Theory. Democracy. Morality and Punishment, Vol. 56, № 118, pp.1-14. 
36. Mudde C., (2004), «The Populist Zeitgeist», Government and Opposition, Vol. 39 (4), pp. $541-563$.

37. Parties and elections in Europe (2020), available at: www.parties-and-elections.eu/ denmark.html (accessed 10 October 2020).

38. Politique: «Populiste», une injure riche de sens (2016), available at: www.slate.fr/story/71963/populiste-injure-politique-partis (accessed 10 October 2019).

39. Pour le Monde, Mélenchon = Le Pen = po pulistes! (2018), available at: www.marianne.net/ Pour-le-Monde-Melenchon-Le-Pen-populistes-_a215291.html (accessed 10 October 2019).

\section{References:}

1. Antova D. (2016), “Tsetska Tsacheva, veche ofitsialno, kandidatt na GYERB za prezident”, News.bg, 2 October.

2. Bolgarskiy sotsialist S. Stanishev: Vybory byli nechesnymi (2013), available at: www.rbc.ru/politics/13/05/2013/5704084e9a7947fcbd448bb1 (accessed 10 October 2020).

3. Borisov obyavi ofitsialno Tsetska Tsacheva za kandidat-prezident na GYERB: Natsiyata ima nuzhda i ot mayka (doplnena) (2016), Dnevnik.bg., 2 October.

4. BSP otryaza ABV ot pregovorite za obshcha koalitsiya za prezidentskite izbori. Ot stoletnitsata ne sa sglasni s predlozheniya ot partiyata na Prvanov proekt za koalitsionno sporazumenie (2016), Blitz.bg., 23 August.

5. Burdyak V., Makar Yu. (2012), «Populizm - skladova diyalnosti ukrainskikh politichnikh partiy», Ukraina - Evropa - Svit, Vyp. 10, Ternopil, Vyd-vo TNPU im. V. Gnatyuka, ss. 130-138.

6. V Bolgarii antipravitelstvennye mitingi prodolzhayutsya uzhe 100 dney (2020), available at: https://rg.ru/2020/10/17/v-bolgarii-antipravitelstvennye-mitingi-prodolzhaiutsia-uzhe-100-dnej.html (accessed 21 October 2020).

7. V Bolgarii vozobnovilis massovye protesty protiv pravitelstva (2020), available at: www.dw.com/ru/\%D0\%B2-\%D0\%B1\%D0\%BE\%D0\%BB\%D0\%\% B8B5 /a-54192503 (accessed 18 August 2020).

8. Gatsak A. (2020), Sovet Yevropy obvinil Bolgariyu v rasizme po otnosheniyu k tsyganam, available at: https://rg.ru/2020/11/03/sovet-evropy-obvinil-bolgariiu-v-rasizme-po-otnosheniiu-kcyganam.html (accessed 5 November 2020).

9. Grazhdani za evropeysko razvitie na Blgariya (GYERB) (2010), available at: www.gerb.bg/bg/news/spisyk-stanovishta_i_pozicii-3.html (accessed 10 April 2012).

10. Demonstranty v Bolgarii trebuyut otstavki pravitelstva (2013), available at: www.bbc.com/russian/rolling_news/2013/06/130623_rn_bulgaria_protests (accessed 12 April 2016).

11. Dimova Isidora (2016), Novite populizmi i krizata na predstavitelnata demokraciya, Avtoreferat na disertacionen trud za pris"zhdane na obrazovatelnata i nauchna stepen «doktor» po nauchnata specialnost «Politologiya», Sofiya, Universitet za nacionalno i svetovno stopanstvo.

12. Dimova Isidora (2014), «Lica na populizma v s"vremenna B"lgariya», Socialni idei, dvizheniya i politiki, NPI «Dimit"r Blagoev», Sofiya, ss. 213-247.

13. Dimova Isidora (2014), «Grazhdanskiyat bunt sreshchu oligarhiyata v godinata na protestite», Grazhdansko obshchestvo i grazhdanski protesti, Fondaciya „CHoveshchina“, Izd. „Avangard Prima“, Sofiya, ss. 173-184.

14. ИА REGNUM (2015), «Yevrokomissiya vnov kritikuet Bolgariyu za korruptsiyu», available at: https://regnum.ru/news/1888620.html (accessed 12 April 2019).

15. Kiianka I. (2016), Populizm v istorii ta suchasnosti: ideolohichni techii, rukhy ta politychni tekhnolohii: monohrafiia, Lviv, Vyd-vo TzOV «Prostir-M», 387s.

16. Kiianka I. B. (2015), «Populizm u prohramakh politychnykh partii u konteksti derzhavnoho upravlinnia: dosvid krain Tsentralno-Skhidnoi Yevropy», Naukovyi visnyk Uzhhorodskoho natsionalnoho universytetu, Seriia: Politolohiia. Sotsiolohiia. Filosofiia, Uzhhorod, Vyp. 18, ss. 89-92.

17. Kiianka I. B. (2014), «Populizm yak fenomen politychnoho zhyttia», Visnyk Dnipropetrovskoho universytetu, Seriia: Filosofiia. Sotsiolohiia. Politolohiia. Dnipro, Vyp. 23, T. 21, № 9/2, ss. 24-29.

18. Kiianka I. B. (2015), «Populizm yak politolohichna katehoriia», Naukovyi zhurnal Dnipropetrovskoho natsionalnoho universytetu imeni Olesia Honchara, Filosofiia i politolohiia v konteksti suchasnoi kultury, Dnipropetrovsk, №1, ss. 67-75.

19. Kogda narod za korruptsiyu. Uroki rumynskogo: chtoby oboronyat vlast ot nezavisimogo prokurora prishlos sobirat «ruchnoy maydan» (2018), available at: www.novayagazeta.ru/ articles/2018/07/22/77253-kogda-narod-zakorruptsiyu (accessed 12 April 2019). 
20. Lanko D. (2009), «Populizm i politicheskoe uchastie: ulichnye besporyadki v stranah Baltijskogo regiona v 2007-2009 gg.», Politicheskaya ekspertiza: PolitEks, T. 5, № 2, ss. 209-230.

21. Mafiya, von! Otkuda nachalis i kuda vedut protesty v Bolgarii (2020), available at: https://russiancouncil.ru/analytics-and-comments/analytics/mafiya-von-otkuda-nachalis-i-kuda-vedutprotesty-v-bolgarii/ (accessed 30 October 2020).

22. Ni tsar, ni general...(2005), available at: www.paragraph22.bg/22-sedmichnik/read/ni-car-nigeneral / (accessed 10 October 2019).

23. Novyy prezident Bolgarii Rumen Radev. Ya - natovskiy general (2018), available at: https://deschide.md/ru/russian_news/externe_ru/3317/ (accessed 10 October 2019).

24. Opitite da se vzdigne Zhivkov edva li ne do vodeshch blgarski drzhavnik sa zhalki (2001), available at: www.mediapool.bg/opitite-da-se-vazdigne-zhivkov-edva-line-do-vodesht-balgarskidarzhavnik-sa-zhalki-news1870 64.html (accessed 20 May 2010).

25. Podchasov N.A. (2017), «Boyko Borisov: fakty biografii», in: Politicheskie lidery v sovremennoy Vostochnoy Yevrope, Moskva, INION RAN, ss. 31-38.

26. Populizm (2010), available at: http://dic.academic.ru/dic.nsf/enc3p/ 240534; http://dic.academic. ru/dic.nsf/ politology /173 (accessed 22 May 2014).

27. Prem'er-ministri Bolgarii (2017), available at: https://uk.wikipedia.org/ wiki/\%D 0\%9F\% D1\%80\%D0\%B5\% (accessed 10 October 2019).

28. Rumyniyu kritikuyut za pravovuyu reformu (2018), available at: https://ru.euronews.com/2018/10/23/brief-romania-hungary-ing-daphne (accessed 10 October 2019).

29. Simeonov P. GYeRB i Obedinenite patrioti po-skoro imat usloviya v 44-oto Narodno sbranie da izplnyat zayavenite politiki (2017), available at: www.focus-news.net/opinion/2017/04/18/42635/ parvan-simeonov-politolog-gerb-i-obedinenite-patrioti-po-skoro-imat-usloviya-v-44-oto-narodnoSabranie-da-izpalnyat-za-yavenite-politiki (accessed 10 October 2019).

30. Strany Tsentralnoy i Vostochnoy Yevropy - novye chleny Yevropeyskogo soyuza. Problemy bezopasnosti (2010), Moskva, Nauka.

31. Barber T. (2012), «Europe must confront crisis of legitimacy». The Financial Times. 24 April.

32. Bulgarian PM Boricov tendens his government resignation (2016). Reuters. Nov. 14.

33. Le populisme ou la democratie des humeurs (2016), available at: www. liberationfr/france/2012/01/02/le-populisme-ou-la-democratie-des-humeurs785319 (accessed 10 October 2019).

34. Meny Y., Surel Y. (2002), Democracies and the Populist Challenge, New York, Palgrava, 259 p.

35. Moufte Ch. (2009), «The Limits of John Rawl's Pluralism», Theory: A Journal of Social and Political Theory. Democracy. Morality and Punishment, Vol. 56, № 118, pp.1-14.

36. Mudde C., (2004), «The Populist Zeitgeist», Government and Opposition, Vol. 39 (4), pp. 541-563.

37. Parties and elections in Europe (2020), available at: www.parties-and-elections.eu/ denmark.html (accessed 10 October 2020).

38. Politique: «Populiste», une injure riche de sens (2016), available at: www.slate.fr/story/71963/populiste-injure-politique-partis (accessed 10 October 2019).

39. Pour le Monde, Mélenchon = Le Pen = populistes! (2018), available at: www.marianne.net/ Pour-le-Monde-Melenchon-Le-Pen-populistes-_a215291.html (accessed 10 October 2019). 